\title{
STOSUNKI PRACY W WIELKOPOLSKICH MAJĄTKACH ZIEMSKICH W OKRESIE MIĘDZYWOJENNYM
}

\begin{abstract}
Janicki Tadeusz, Stosunki pracy w wielkopolskich majątkach ziemskich w okresie międzywojennym [Labour relations in the Wielkopolska land estates in the interwar period] edited by W. Banach - „Człowiek i Społeczeństwo”, vol. XXXVIII, Poznań 2014, pp. 81-97, Adam Mickiewicz
\end{abstract} University Press. ISBN 978-83-232-2791-5. ISSN 0239-3271.

In the period between the two world wars large landowners in the Wielkopolska region employed the largest number of hired labourers in the area. The main subject of this article is the professional and personal relations between land estate owners and the two main groups of hired workers (the economic administration staff and the farm workers). The labour relations in Wielkopolska's land estates were based on a strictly observed hierarchy and division of duties. In interpersonal relations we may notice some patriarchal and technocratic elements. In the case of the former, they were mainly inspired by the landowners (or, in a wider sense, by the residents of the manor house), while the technocratic elements were contributed mainly by the administration staff. The labour relations on land estates were slowly evolving under the influence of legal regulations and were additionally shaped by the economic and cultural developments. The impact of this process on the actual organization of labour was rather limited. It was much more evident in the change of relations between people, which evolved mainly under the influence of the process of change in the consciousness of agricultural workers to replace traditional relations, based on patriarchal ones and manoralism or serfdom-based relations, into professional and contract-based labour relations. However, the trends to modernise the land estates during the 1920s, both in the sphere of technology and social relations, became impeded by the impact of the economic crisis of the 1930s which led again to further consolidation of the patriarchal employer-employee model of relations.

Tadeusz Janicki, Uniwersytet im. Adama Mickiewicza w Poznaniu, Instytut Historii, Zakład Historii Gospodarczej, ul. Św. Marcin 78, 61-809 Poznań, Poland.

W XIX wieku na ziemiach polskich pod zaborem pruskim, $\mathrm{w}$ rezultacie zapoczątkowanej przez reformy uwłaszczeniowe tzw. pruskiej drogi do kapitalizmu w rolnictwie, powstała struktura agrarna, w której dominowały majątki ziemskie i duże gospodarstwa chłopskie zatrudniające stałych i sezonowych robotników rolnych. $\mathrm{W}$ tym okresie $\mathrm{w}$ majątkach ziemskich ukształtowały się zasady organizacyjne dotyczące zarówno produkcji rolnej, 
jak i liczby, struktury oraz hierarchii zatrudnianych w nich pracowników, które przetrwały upadek Rzeszy Niemieckiej i funkcjonowały dalej po odzyskaniu przez Polskę niepodległości. Przedmiotem niniejszych rozważań są pracodawcy i pracobiorcy oraz zachodzące pomiędzy nimi stosunki o charakterze zawodowym, przedstawione $\mathrm{z}$ uwzględnieniem organizacji pracy $\mathrm{w}$ wielkopolskich majątkach ziemskich $\mathrm{w}$ okresie międzywojennym. W krótkim opracowaniu trudno o szczegółową charakterystykę tak złożonego zjawiska, dlatego należy je traktować jako ogólny szkic, sygnalizujący jedynie najważniejsze problemy $\mathrm{z}$ dziedziny stosunków pracy $\mathrm{w}$ wymienionych wyżej przedsiębiorstwach rolnych. Pod względem rzeczowym obejmuje ono stosunki pracy zachodzące $\mathrm{w}$ ramach wąsko rozumianej produkcji rolnej (uprawa roślin i hodowla zwierząt), zaś pomija te związane z gospodarką leśną, ogrodnictwem i pracą w należących do majątków zakładach przemysłowych, takich jak gorzelnie, cegielnie itp. Ramy terytorialne, do jakich odnosi się opracowanie, to teren województwa poznańskiego w granicach administracyjnych ustalonych po I wojnie światowej ${ }^{1}$.

W okresie międzywojennym w rolnictwie Wielkopolski wielka własność ziemska zajmowała pozycję dominującą. W jej posiadaniu w 1921 roku znajdowało się 51\%, w 1931 roku - 49,3\%, a w 1938 roku - 47,3\% gruntów rolnych ${ }^{2}$. Były to majątki średniej wielkości (od 200 ha do 500 ha) prowadzące gospodarkę kapitalistyczną, $\mathrm{z}$ reguły dobrze zorganizowane, zmechanizowane i uprzemysłowione oraz zatrudniające dużą liczbę stałych robotników rolnych, a osiągane przez nie wyniki produkcyjne były wyższe niż w innych regionach Polski. W około $30 \%$ majątków znajdowały się zakłady przemysłu rolno-spożywczego, tartaki lub cegielnie ${ }^{3}$.

Wśród właścicieli majątków ziemskich pod względem narodowościowym dominowali Polacy, ale liczną grupę stanowili również Niemcy.

1 Obszar województwa zmienił się od 1 kwietnia 1938 roku, kiedy to odłączono od niego powiaty: bydgoski miejski, inowrocławski, inowrocławski miejski, szubiński i wyrzyski, oraz trzy gminy z powiatu mogileńskiego (przyłączone do województwa pomorskiego), i przyłączono powiaty: kaliski, kolski, koniński i turecki. Jednak zasadnicze dla niniejszych rozważań umowy zbiorowe dla wielkopolskiego rolnictwa na lata 1919-1939 nie objęły nowych części województwa. Por. A. Czubiński, Wielkopolska w latach 1918-1939, Wydawnictwo Poznańskie, Poznań 2000, s. 167-168; S. Warkoczewski, Położenie robotników rolnych w Wielkopolsce w latach 1929-1939, Książka i Wiedza, Warszawa 1965, s. 6.

2 Por. S. Nowakowski, Geografia gospodarcza Polski zachodniej, t. 1, Pomorska Drukarnia Rolnicza Sp. Akc., Poznań 1929, s. 162; W. Roszkowski, Gospodarcza rola większej prywatnej własności ziemskiej w Polsce 1918-1939, Szkoła Główna Planowania i Statystyki, Warszawa 1986, s. 126.

${ }^{3} \mathrm{~W}$ statystykach międzywojennych i powojennej literaturze przedmiotu za wielką własność ziemską przyjęło się uważać gospodarstwa powyżej 50 ha, gospodarstwa od 50 ha do 100 ha określano jako przejściowe, a dopiero powyżej tej granicy jako wielkie. 
W 1921 roku na 2560 gospodarstw powyżej 50 ha do Niemców należało 1051, czyli 40,9\%, a zajmowały one powierzchnię 389500 ha, czyli 36,2\% obszaru wielkiej własności w regionie. Obszar ziemi w niemieckim posiadaniu stopniowo kurczył się i w 1934 roku wynosił już tylko 26,3\% ${ }^{4}$.

W okresie międzywojennym liczba wielkich właścicieli ziemskich i folwarków stopniowo malała. W 1921 roku w Wielkopolsce było 2576, a w 1938 roku 2475 właścicieli ziemskich (powyżej 50 ha), co oznacza, że ich liczba zmniejszyła się o około 4\%. Z kolei liczba folwarków w latach 1923-1937 spadła z 2148 do 1864, czyli o około 14\%5. Powyższe zmiany z jednej strony wynikały $\mathrm{z}$ niekorzystnej koniunktury $\mathrm{w}$ rolnictwie i postępującej parcelacji, z drugiej - ze zmian społeczno-ekonomicznych polegających na poszukiwaniu przez ziemian lepiej płatnej pracy w miastach, gdzie zajmowali się sferą finansowo-przemysłową, wykonywali wolne zawody lub pracowali jako urzędnicy ${ }^{6}$.

Pracownicy najemni w majątkach ziemskich dzielili się na trzy grupy: pracowników administracji gospodarczej, robotników rolnych i służbę dworską. Grupy te różniły się zasadniczo co do charakteru świadczonej pracy i miejsca w hierarchii pracowniczej majątku. Przedmiotem artykułu są dwie pierwsze grupy bezpośrednio związane z produkcją rolną. Liczba pracowników oraz sposób zarządzania majątkiem zależały przede wszystkim od wielkości majątku, liczby samodzielnych gałęzi produkcji i stopnia zaangażowania się właściciela $\mathrm{w}$ bezpośrednie zarządzanie. W Wielkopolsce dominowały majątki kierowane osobiście przez właściciela, choć praktykowano również zarządzanie za pośrednictwem plenipotenta lub administratora oraz wydzierżawianie majątku. Jednak samodzielne zarządzanie majątkiem uważano za korzystniejsze ekonomicznie i odpowiadające ideologii ziemiańskiej, zgodnie z którą pracę na roli traktowano jako obowiązek moralny i patriotyczny ${ }^{7}$. Z dostępnych źródeł wynika, że forma kierowania folwarkiem nie miała większego wpływu na organizacje pracy, zarządzanie i stosunki pracownicze. Porównanie kilku majątków z różnych części Wielkopolski potwierdza daleko idące podobieństwo w tej dziedzinie. Wynikało to między innymi z czynników o charakterze normatywnym i organizacyjnym, które były jednolite dla całej Wielkopolski. W tym przypadku chodzi

${ }^{4}$ Por. R. Dąbrowski, Niemieckie majątki obszarnicze w województwach zachodnich w latach 1920-1939, „Przegląd Zachodniopomorski” 1978, t. XXII, z. 2, s. 74-78; Statystyka Rolna, odbitka z „Miesięcznika Statystycznego" 1922, z. 12, s. 14; W. Roszkowski, Gospodarcza rola..., s. 57-58.

${ }_{5}^{5}$ Por. S. Kowal, Struktura społeczna Wielkopolski w międzywojennym dwudziestoleciu, Wydawnictwo Naukowe UAM, Poznań 1974, s. 51; W. Roszkowski, Gospodarcza rola..., s. 102.

6 S. Kowal, op. cit., s. 90-93.

7 W. Mich, Ideologia polskiego ziemiaństwa 1918-1939, Wydawnictwo UMCS, Lublin 2000, s. 248. 
głównie o: umowy taryfowe z robotnikami rolnymi oraz działalność Związku Producentów Rolnych, Związku Ziemian i Wielkopolskiej Izby Rolnej, które udzielały folwarkom fachowej pomocy merytorycznej $\mathrm{w}$ dziedzinie produkcji rolnej i hodowli oraz wydawały zalecenia co do postępowania w stosunkach z robotnikami ${ }^{8}$. Ogólnie rzecz biorąc, prowadzenie majątku ziemskiego polegało na zgromadzeniu koniecznych kapitałów i środków produkcji, zaplanowaniu, organizacji i nadzorze robót. Z reguły właściciel sprawował ogólny nadzór nad funkcjonowaniem majątku, pozostawiając do swojej dyspozycji decyzje dotyczące profilu produkcji, sprawy finansowe i handlowe oraz nadzór nad księgowością i kasą. W zależności od wielkości majątku w zarządzaniu właścicielowi pomagała większa lub mniejsza liczba pracowników administracji gospodarczej, do której należeli samodzielni administratorzy i rządcy majątków oraz urzędnicy niesamodzielni (rządcy, buchalterzy, kasjerzy, leśniczy) i pomocnicy gospodarczy (włodarze, pisarze, magazynierzy, urzędnicy biurowi i podleśniczy lub borowi) ${ }^{9}$.

W dziedzinie produkcji rolnej zasadniczą rolę odgrywali rządcy poszczególnych folwarków. Do ich obowiązków należało wykonywanie poleceń właściciela lub administratora, nadzór nad wydajnością pracy robotnika, pilnowanie mienia właściciela i prawidłowe prowadzenie ksiąg gospodarskich. $Z$ reguły mieli spory zakres samodzielności w podejmowaniu decyzji, a zatwierdzeniu przez właściciela podlegały jedynie najważniejsze $\mathrm{z}$ nich. Jednocześnie rządcy w okresie obowiązywania umowy nie mogli prowadzić żadnej działalności gospodarczej na własny rachunek, a w razie naruszenia umowy byli zwalniani natychmiast lub za wypowiedzeniem ${ }^{10}$. Stanowisko

${ }^{8}$ M. Markowski, Ziemianie jako pracodawcy w Drugiej Rzeczypospolitej, [w:] Dwór a społeczności lokalne na ziemiach polskich w XIX i XX wieku, red. M. Markowski, W. Caban, M. Przeniosło, Wydawnictwo UH-P, Kielce 2008, s. 322; G. Jassem, Majatek Smogulecki w latach 1918-1937, PTPN, Poznań 1976, s. 127-128; E. Potworowski, Majętność Gola, Rolnicza Drukarnia i Księgarnia Nakładowa, Poznań 1929, s. 17-18.

${ }_{9} \mathrm{~W}$ gronie pracowników administracyjnych szczególną pozycję mieli administratorzy, rządcy i leśniczy, gdyż w przydzielonym im zakresie czynności mogli podejmować samodzielne decyzje, które były z reguły jedynie potwierdzane przez właściciela lub przełożonego (czyli np. administratora w stosunku do rządców i leśniczych). Zob. J. Kozakiewicz, Organizacja pracy $i$ wyniki produkcyjne $w$ majątkach ziemskich $w$ okresie międzywojennym, IUNG, Puławy 1986, s. 22. Według międzywojennego badacza kwestii agrarnych Jerzego Walickiego pracownicy majątku, zarówno administracyjni, jak i fizyczni, powinni być: zdrowi, uczciwi, inteligentni, słowni, stanowczy, energiczni, pracowici, dokładni, spostrzegawczy, posiadający zamiłowanie do porządku, zmysł oszczędności, zdrowy rozsądek, takt $\mathrm{w}$ stosunkach $\mathrm{z}$ innymi ludźmi oraz odwagę w podejmowaniu decyzji. Był to swoisty ideał, ale dążenie do osiągnięcia powyższych cech u pracowników było, zdaniem Walickiego, jednym z warunków sprawnego funkcjonowania majątku. Zob. J. Walicki, Zagadnienie zarzadzania gospodarstwami folwarcznymi, "Gazeta Rolnicza" 1934, nr 47, s. 1242.

${ }^{10}$ G. Jassem, op. cit., s. 133. 
pośrednie pomiędzy administracją gospodarczą a robotnikami rolnymi zajmował włodarz (zwany również karbowym lub ekonomem), podlegający (w zależności od wielkości majątku) bezpośrednio właścicielowi albo administratorowi lub rządcy. Ze względu na pełnioną funkcję można go zaliczyć do administracji gospodarczej, jednak $\mathrm{z}$ formalno-prawnego punktu widzenia był robotnikiem rolnym zaliczanym do grupy ordynariuszy. W większych gospodarstwach było kilku włodarzy, przede wszystkim od prac polowych, ale także od prac wykonywanych końmi. Włodarze najczęściej wywodzili się z robotników rolnych pracujących $\mathrm{w}$ danym majątku i byli awansowani ze względu na swoją solidność i umiejętności fachowe ${ }^{11}$. Najliczniejszą grupę pracowników najemnych pracujących w majątkach ziemskich stanowili robotnicy rolni. Określenie ich dokładnej liczby nastręcza trudności, gdyż źródła statystyczne wykazują jedynie tych, którzy podpisali umowę o pracę, a z reguły nie obejmują robotników sezonowych i dorywczych, których zatrudniano na podstawie umowy ustnej. W literaturze przedmiotu przyjmuje się, że stale zatrudnieni stanowili około $60 \%$ ogólnej liczby zatrudnionych ${ }^{12}$. Dane dotyczące liczby czynnych zawodowo robotników folwarcznych w Wielkopolsce według typów zatrudnienia zawiera tabela.

Tabela. Liczba zawodowo czynnych robotników folwarcznych w Wielkopolsce według typów w latach 1921 i 1931

\begin{tabular}{|l|c|c|}
\hline \multirow{2}{*}{\multicolumn{1}{c|}{ Typ }} & \multicolumn{2}{c|}{ Lata } \\
\cline { 2 - 3 } & $\mathbf{1 9 2 1}$ & $\mathbf{1 9 3 1}$ \\
\hline Ordynariusze & 43848 & 31333 \\
\hline Zaciężnicy & 56820 & 62971 \\
\hline Chałupnicy & 6975 & 10639 \\
\hline Rzemieślnicy & 5330 & 5560 \\
\hline Wolni $^{a}$ & 8999 & 3900 \\
\hline Razem & 121972 & 114403 \\
\hline
\end{tabular}

a - robotnicy rolni zatrudniani w czasie spiętrzenia robót (np. podczas żniw) na okres krótszy niż jeden miesiąc, niezwiązani na stałe z majątkiem. Określano ich również jako robotników wolnonajemnych lub dniówkowych niestałych.

Źródło: S. Warkoczewski, op. cit., s. 39, 49.

${ }^{11}$ J. Kozakiewicz, op. cit., s. 26-27.

12 Robotnicy rolni zatrudnieni $\mathrm{w}$ województwach poznańskim i pomorskim stanowili około 30\% wszystkich robotników folwarcznych w Polsce, których ogólną liczbę w 1921 roku szacowano na 620 tys. osób (zawodowo czynnych), w 1932 roku na 600 tys., a w 1938 roku na około 520 tys. Jeśli chodzi o liczbę pracowników stałych, to w tychże województwach zatrudniona była połowa ich ogólnej liczby. Por. W. Roszkowski, Rolnictwo i leśnictwo, [w:] Problemy gospodarcze drugiej Rzeczypospolitej, red. K. Kozłowski, PWE, Warszawa 1989, s. 114; S. Kowal, op. cit., s. 50; S. Warkoczewski, op. cit., s. 51, 58. 
Jak wynika z powyższej tabeli, liczba pracowników folwarcznych $\mathrm{w}$ okresie międzywojennym zmalała, szczególnie w latach kryzysu gospodarczego. Zmniejszyła się również średnia liczba robotników przypadająca na jeden folwark, z 63 w 1929 roku do 60 w roku 193713.

Od 1919 roku warunki pracy i płacy robotników rolnych w Wielkopolsce i na Pomorzu regulowane były przez umowy zbiorowe, corocznie negocjowane przez przedstawicieli Związków Zawodowych i organizacje reprezentujące właścicieli ziemskich przy współudziale państwowej Inspekcji Pracy. Do rozstrzygania sporów pomiędzy pracodawcami i pracobiorcami powołano w 1921 roku Nadzwyczajną Komisję Rozjemczą, która ustalała treść „kontraktów taryfowych”, gdy wspomniane wyżej strony nie mogły dojść do porozumienia. Umowy zbiorowe, które polepszały położenie robotników rolnych, od samego początku okresu międzywojennego były krytykowane przez pracodawców. Konsekwentnie dążyli oni do ich likwidacji lub przynajmniej ograniczenia ich zakresu. Korzystając z trudnej sytuacji na rynku pracy w okresie kryzysu, od 1932 do 1935 roku właściciele przymuszali robotników do podpisywania w miejsce umów zbiorowych zdecydowanie mniej korzystnych umów indywidualnych. Powyższe działania spotkały się z przeciwdziałaniem władz, które za cenę obniżenia płac utrzymały w mocy obowiązywanie umów zbiorowych na terenie Wielkopolski aż do 1939 roku$^{14}$.

Według rodzaju zawartej umowy robotników rolnych zatrudnianych w wielkopolskich majątkach można podzielić na następujące kategorie: a) ordynariusze (zwani także deputatnikami), a wśród nich fornale, ręczniacy, kotarze, włodarze, rzemieślnicy i stróże (otrzymujący wynagrodzenie w formie deputatu, na który składało się mieszkanie, naturalia i niewielka suma pieniędzy); b) posyłki (inaczej najemni albo zaciężnicy, przeważnie członkowie rodzin ordynariuszy lub osoby zatrudnione przez nich, jeśli nie mieli dzieci zdolnych do pracy) otrzymujący wynagrodzenie najczęściej w gotówce i częściowo w naturaliach; c) chałupnicy i komornicy - na ogół niemieszkający $\mathrm{w}$ folwarku robotnicy półstali, zobowiązani do przepracowania określonej liczby dni w roku, otrzymujący wynagrodzenie w gotówce i naturaliach; d) robotnicy sezonowi - zakontraktowani na krótki okres (z reguły trzy miesiące), otrzymujący wynagrodzenie mieszane z przewagą gotówki15. Zatrudnieni na stałe ordynariusze poza deputatem i niewielką

${ }^{13} \mathrm{~K}$. Chmielewski, Ilość osób zatrudnionych w wielkorolnych gospodarstwach poznańskich (lata 1932/33 - 1933/34), „Roczniki Nauk Rolniczych i Leśnych” vol. XXXIX, Poznań 1937, s. 94-96.

14 Archiwum Państwowe w Poznaniu (dalej: APP), Inspekcja Pracy w X okręgu w Poznaniu (dalej: IP), sygn. 39, k. 81-87, 175-21; S. Warkoczewski, op. cit., s. 107-117.

${ }^{15}$ W. Roszkowski, Rolnictwo..., s. 148-151; G. Jassem, op. cit., s. 122-125. 
sumą $\mathrm{w}$ gotówce otrzymywali także inne świadczenia, $\mathrm{w}$ tym: mieszkanie, opał, utrzymanie inwentarza, ziemię pod ziemniaki i transport (np. drewna opałowego z lasu). Szczególnie ważny czynnik przyciągający i wiążący ordynariuszy $\mathrm{z}$ folwarkiem stanowiły mieszkania, jednak niezwykle często były one prymitywne i w bardzo złym stanie technicznym, zdaniem jednego z przedstawicieli Inspekcji Pracy - „urągającym wszelkim najelementarniejszym zasadom higieny"16.

Opisana forma zatrudniania ordynariuszy zapewniała stałą i wykwalifikowaną siłę roboczą $\mathrm{w}$ gospodarstwie o każdej porze roku, zaś forma zapłaty $\mathrm{w}$ naturaliach była korzystna zarówno dla pracownika (zabezpieczała przed spadkiem wartości pieniądza), jak i pracodawcy, dla którego stanowiła jedną z form sprzedaży produktów rolnych. Ordynariusz i jego rodzina stanowili "główną jednostkę roboczą" w majątku oraz zasadnicze źródło zaciężników. Część z tych ostatnich uznana przez właściciela lub rządcę za szczególnie przydatnych z biegiem czasu awansowała i uzyskiwała status ordynariuszy. Wśród ordynariuszy najlepiej opłacani byli rzemieślnicy (kowal, stelmach, murarz, cieśla) i wykwalifikowani robotnicy rolni ${ }^{17}$. Duża liczba ordynariuszy i zaciężników, wynosząca od $60 \%$ do $80 \%$ wszystkich stale zatrudnionych, była charakterystyczna dla wielkiej własności ziemskiej w Wielkopolsce i na Pomorzu.

Czas pracy $\mathrm{w}$ wielkopolskich majątkach ziemskich (zgodnie z taryfą) średnio w roku wynosił 9 godzin i 25 minut dziennie bez wliczania przerw na posiłek i odpoczynek. W zależności od pory roku łączny czas pracy (z przerwami) wahał się od 6 godzin i 30 minut zimą do 11 godzin latem. Jednak czas pracy fornali i innych robotników zatrudnionych przy inwentarzu pociągowym był dłuższy, gdyż karmienie i czyszczenie zwierząt oraz przygotowanie pojazdów zgodnie z zapisami taryfowymi miało się odbywać poza wyznaczonym na dany okres czasem pracy, choć nie wcześniej niż dwie godziny przed rozpoczęciem i po zakończeniu pracy przez innych robotników rolnych. Powyższe ustalenia taryfowe były często łamane w związku z nagminnym wydłużaniem czasu pracy, co prowadziło do wielu konfliktów pomiędzy pracownikami a administracją gospodarczą ${ }^{18}$.

${ }^{16}$ K. Wize, Położenie robotników rolnych w Poznańskiem po wojnie, Druk. Sp. Akc. „Ostoja”, Poznań 1925, s. 17-23; APP, IP, sygn. 59, k. 321.

17 Ordynariuszy zatrudniano na rok gospodarczy, od 1 kwietnia danego roku do 31 marca roku następnego. Jeżeli do 31 grudnia ordynariusz nie otrzymał zwolnienia na piśmie (w Wielkopolsce zwanego terminatką), umowa zostawała przedłużona na rok następny. Robotnik mógł sam wymówić pracę, również do 31 grudnia. Por. M. Mieszczankowski, Rolnictwo II Rzeczypospolitej, Książka i Wiedza, Warszawa 1983, s. 365; S. Warkoczewski, op. cit., s. 73-80; J. Kozakiewicz, op. cit., s. 32-33.

${ }^{18}$ APP, IP, sygn. 38, k. 289. 
Z oczywistych względów inny czas pracy niż zwykli robotnicy rolni (np. ręczniacy) mieli stróże i dozorcy, którzy podejmowali swoje obowiązki po opuszczeniu zabudowań folwarcznych przez fornali, a kończyli zajęcia rano, gdy rozpoczynano karmienie inwentarza. Zgodnie z umowami zbiorowymi, $\mathrm{w}$ razie pilnej potrzeby, można było (za dodatkowym wynagrodzeniem) wydłużyć czas pracy robotników, jednak w dni świąteczne tylko za ich zgodą ${ }^{19}$.

Zawód robotnika rolnego w zdecydowanej większości przypadków był dziedziczony po rodzicach, a wówczas przygotowanie zawodowe $\mathrm{z}$ reguły następowało poprzez tzw. „wrastanie” w system gospodarki folwarcznej oparte na naśladownictwie i praktycznej edukacji, w której nauczycielami na ogół byli rodzice i rodzeństwo. Poprzez obserwację i uczestnictwo w życiu folwarku dziecko nie tylko uczyło się pracy na roli, ale również rozwijała się w nim świadomość folwarku jako systemu hierarchicznego i rygorystycznego ${ }^{20}$. Proces wrastania dziecka w system gospodarki folwarcznej podlegał różnym odchyleniom. $Z$ jednej strony istniały rodziny robotnicze, w których rodzice wkładali szczególnie wiele wysiłku w zaszczepianie dziecku cnót, jakich wymagał dwór i folwark. $Z$ takich rodzin przeważnie pochodziła późniejsza służba dworska, a także robotnicy folwarczni awansujący na wyższe stanowiska. Z drugiej strony dla części rodziców folwarczna przyszłość ich dziecka była mało atrakcyjna. Szczególnie w okresach dobrej koniunktury w przemyśle i związanego z tym masowego odpływu robotników rolnych do miast oraz pod wpływem porównywania warunków pracy na roli z warunkami pracy i płacy w przemyśle, niektórzy z nich starali się zapewnić przynajmniej części dzieci pracę poza folwarkiem. Zdaniem pracodawców poza lepszymi warunkami pracy w przemyśle negatywnie na wrastanie dziecka w system folwarczny oddziaływały również: ograniczenie pracy kobiet $\mathrm{w}$ majątku, co pozwalało na zmniejszenie zatrudniania dziecka $w$ gospodarstwie domowym, ustawowy zakaz zatrudniania dzieci poniżej 15. roku życia w gospodarstwie obcym oraz tzw. „urbanizacja duchowa", na którą składały się: oświata, rozwój związków zawodowych i docieranie do robotnika różnych bodźców ze świata zewnętrznego, w tym nieprzyjaznej dla folwarku propagandy politycznej21.

${ }^{19}$ K Wize, op. cit., s. 13-15; S. Warkoczewski, op. cit., s. 118-121.

${ }^{20}$ Rzecz jasna, nie wszyscy robotnicy pracujący na danym folwarku urodzili się na nim. Wielu pochodziło z innych folwarków, na ogół jednak terytorialny zakres migracji nie był wielki, wobec czego istniały możliwości przenoszenia z jednego folwarku na drugi tych wyników rozwoju, które były aktualne i tu, i tam. Por. M. Wachowski, Przygotowanie zawodowe robotnika rolnego w świetle pedagogiki empirycznej, „Roczniki Nauk Rolniczych i Leśnych” vol. XLVII, Poznań 1939, s. 111, 116, 120.

21 Ibidem, s. 122. 
Przełomowym momentem dla dziecka wrastającego $\mathrm{w}$ folwark było ukończenie 15. roku życia, gdyż w odniesieniu do dzieci ordynariuszy oznaczało to $\mathrm{z}$ reguły początek regularnej pracy $\mathrm{w}$ najniższej kategorii pracowniczej, obejmującej chłopców i dziewczęta od 15. do 16. roku życia. Wykonywali oni najlżejsze prace, na ogół takie same, najczęściej w nadzorowanej grupie, czyli tzw. "partii”. Gdy nowicjuszom wyznaczano trudniejsze zadania, dołączano ich do starszych pracowników, jednak dbano, żeby to nie były prace, przy których „można się oberwać”. Po jednorocznym nowicjacie młodzi robotnicy przechodzili do drugiej kategorii, przeważnie dwuletniej, obejmującej chłopców i dziewczęta od 16 do 18 lat. Na tym etapie do wcześniej wykonywanych prac dochodziły niektóre trudniejsze lub wymagające większej siły fizycznej, np. sadzenie ziemniaków. Trzecia kategoria zaczynała się po ukończeniu przez młodych ludzi 18. roku życia. Na tym etapie robotnik miał być zdatny do wszystkich robót, które jednak silniej niż poprzednio różnicowano według płci pracowników, w związku z czym rozdzielano dziewczęta i chłopców. Młodzi pracownicy ze wszystkich trzech wymienionych grup wiekowych należeli do tzw. zaciągu i byli opłacani zgodnie z umowami zbiorowymi. Pracownicy tej kategorii (zaciężnicy) nie stanowili głównego typu robotnika folwarcznego, ani też nie nawiązywali z folwarkiem samodzielnie stosunku służbowego - wynikał on z przynależności do rodziny ordynariusza. Awans na ordynariusza nie był automatyczny, gdyż okres pracy na stanowisku zaciężnika służył między innymi do eliminacji "typów niezdatnych" zgodnie z zasadą, że "niedołęga nie zostaje ordynariuszem”. W warunkach braku robotników powyższy awans mógł być dość szybki, jednak w wypadku pełnej obsady folwarku (szczególnie w czasach kryzysu) zaciężnik musiał czekać nieraz kilka lat, co niejednokrotnie skutkowało tym, że musiał na później odkładać małżeństwo (o ile nie dostał pomieszczenia dla siebie i żony $\mathrm{w}$ mieszkaniu rodziców), ponieważ tylko ordynariusz otrzymywał osobne mieszkanie służbowe ${ }^{22}$.

Wrastanie w zbiór wartości związanych z gospodarstwem folwarcznym nie kończyło się wcale $\mathrm{z}$ chwilą awansu na ordynariusza. Powyższy proces trwał nadal, gdyż w opinii rządców pełnowartościowym robotnikiem stawał się mężczyzna dopiero około 45. roku życia. W związku z powyższym na rządcach, poza zadaniami produkcyjnymi, ciążyły obowiązki o charakterze wychowawczym, dotyczące zarówno umiejętności zawodowych robotnika, jak i kształtowania jego świadomości w duchu „życzliwości dla folwarku”. Dlatego też podkreślano, że dobry kierownik folwarku powinien oddziaływać na usposobienie swych podwładnych, a w szczególności na ich stosu-

22 Ibidem, s. 102-105. 
nek do pracy, tak żeby odpowiednio wychowany robotnik „nie tylko sam oddychał pożądaną postawą do pracy, ale zaszczepiał ją innym, także swojemu otoczeniu domowemu". Powyższa działalność pedagogiczna miała stanowić formę obrony folwarków przed urbanizacją duchową i konkurencją przemysłu23.

W czasach dobrej koniunktury na rynku pracy brakowało wykwalifikowanych i solidnych robotników rolnych. W związku z tym właściciele i rządcy poświęcali sporo czasu na pozyskiwanie, charakterystykę i ocenę przydatności oraz wspomniane wychowanie robotników rolnych, zwłaszcza że ich wymagania co do jakości pracowników były bardzo wysokie. Obowiązki zawodowe oraz zasady zachowania robotników rolnych wobec właściciela, przełożonych i powierzonego im mienia kontrakty taryfowe precyzowały w następujący sposób: „pracowników obowiązuje grzeczność wobec pracodawców i ich zastępców, ścisłe przestrzeganie zawartych umów, pilne i sumienne spełnianie obowiązków, dążność do największej wydajności pracy i stosowanie się do zarządzeń pracodawcy lub jego zastępcy, odnoszących się do wykonania obowiązków służbowych oraz przestrzeganie wszystkich przepisów porządkowych $\mathrm{w}$ obrębie folwarku, jak też dbałe i staranne obchodzenie się z powierzonym sobie inwentarzem żywym i martwym"24. Poza tym od kandydatów na robotnika rolnego wymagano, żeby mieli: "silną budowę ciała, zdrowe ręce i nogi [...] staranną i pełną zrozumienia rękę, zamiłowanie do przyrody, szczególne zrozumienie dla świata zwierzęcego i roślinnego, zdolność do samodzielnego i odpowiedzialnego wykonywania robót oraz na wsi przeżytą młodość". Ponadto oczekiwano, iż będą "uczciwi, odpowiedzialni, solidaryzujący się z systemem gospodarki folwarcznej, rozumiejący, że interes majątku jest także jego interesem oraz ambitni i ufający przełożonym" 25 .

Jak wynika z powyższego, oczekiwania pracodawców i rządców były bardzo wysokie. Jednak na podstawie ogłoszeń prasowych, w których poszukiwano pracowników folwarcznych, można stwierdzić, że wymienione wyżej wymagania stawiano prawie wyłącznie stangretom, włodarzom i stróżom, a jedynie sporadycznie kandydatom na robotnika szeregowego. Wymagania dotyczyły także niepracujących członków rodziny robotnika i jego zachowania się poza pracą. Poza obowiązkami zawodowymi wymagano poszanowania własności, wywierania na dzieci wpływu w kierunku wartości pożądanych przez dwór i folwark, przestrzegania zgody sąsiedzs. 118.

${ }_{23}$ S. Warkoczewski, op. cit., s. 8; M. Wachowski, Przygotowanie zawodowe robotnika...,

${ }^{24}$ M. Wachowski, Przygotowanie zawodowe robotnika..., s. 95.

${ }^{25}$ Ibidem, s. 95-96. 
kiej oraz zasad higieny, w tym zwłaszcza lepszego odżywiania się i zasad czystości ${ }^{26}$.

Przykład wymagań stawianych robotnikom i jednocześnie, używając dzisiejszego języka, zarządzania kadrami mogą stanowić charakterystyki robotników sporządzone przez rządcę majątku w Wierzenicy, który o poszczególnych pracownikach pisał jak następuje:

1. „Inteligencja bardzo słaba, typ kretyna, niechlujny, mało dba o siebie, to samo w pracy".

2. "Nie dbał o konie, obecnie utemperowany, inteligentny, posyła się go do miasta - trudniejsze zadania".

3. „Pierwszorzędna, dbała, ambitna, wzorowa”.

4. "Typ szablonowy, słabo kombinuje, pracownik słaby, zawodzi wobec zadań nowych, charakter skryty, zawsze drwiący".

5. "Robotę każdą wykona pierwszorzędnie, bardzo obowiązkowy i dbały, wszystko w lot zrozumie, duży zmysł kombinatorski, robota go zajmuje, najlepszy i najzdolniejszy robotnik, żal zrobić włodarzem, bo straci się najlepszego robotnika, zresztą nie nadaje się; mało poważny, stroi żarty z dziewczynami, byłby za to dobrym rzemieślnikiem".

6. „Typ dodatni, nie został włodarzem, bo pił; zna pracę, co tu rzadko się zdarza, bardzo porządny człowiek".

7. „Zawadiaka, był w więzieniu, bardzo zdolny, sprytny, załatwia wszelkie sprawunki w mieście, nawet w urzędach, trafi wszędzie, doskonale się orientuje".

8. „Pracownik niedołężny, wszystko robi niezdarnie, mało sprytu, jedyny plus, że dba o konie, uczciwy, żona go strofuje, że z podwórza nic nie przynosi".

9. "Chytrus i lizus, umie się przypłaszczyć, przeciętny jako pracownik".

10. „Miejscowa inteligencja, rozgarnięty, taktowny, wyrobiony, wiosną chciał odejść na lepszą pracę. Był 4 tygodnie w Poznaniu, zwolnili go, w końcu przyszedł prosić o robotę, przedtem był fornalem, teraz na razie jako obcy za karę za odejście do miasta" 27.

${ }^{26}$ Od stangreta wymagano często między innymi odbytej służby wojskowej w kawalerii, „większej praktyki”, niekiedy „umiejętności rymarskich”. Włodarz zaś miał być najczęściej "energiczny", rzadziej natomiast "taktowny w obchodzeniu się z podwładnymi", ponadto "stanowczy, zamiłowany w dobrym wyglądzie koni, uczciwy, solidny, sumienny, dzielny, doświadczony w gospodarce rolnej, rutynowany, obeznany z uprawą roli, leczeniem bydła". Stróż polowy natomiast miał być na ogół „bardzo energiczny” i „bezwzględnie uczciwy”. Por. M. Wachowski, Przygotowanie zawodowe robotnika..., s. 97.

27 Ibidem, s. 97-98. 
Stosunki pracy $\mathrm{w}$ wielkopolskich majątkach ziemskich oparte były na ściśle przestrzeganej hierarchii, która obowiązywała nie tylko w relacjach pomiędzy właścicielem, pracownikami administracji gospodarczej i robotnikami rolnymi, ale także wewnątrz ostatniej grupy. Była ona wewnętrznie podzielona według typu kontraktu, zajmowanego stanowiska, wysokości deputatu i płac gotówkowych oraz według miejsca pracy, na tych z dworu i tych $\mathrm{z}$ folwarku, co w dużej mierze stanowiło kopię $\mathrm{w}$ tym względzie podziałów wywodzących się z poprzednich wieków ${ }^{28}$. W stosunkach międzyludzkich $\mathrm{w}$ majątkach ziemskich $\mathrm{w}$ okresie międzywojennym można dostrzec elementy patriarchalne i technokratyczne. Nosicielem i strażnikiem tradycji patriarchalnej był właściciel majątku lub szerzej - mieszkańcy dworu. Szczególnie wyraźnie pozostałości patriarchalizmu widoczne były w trakcie bezpośrednich kontaktów pracowników z właścicielem (jak to wtedy określano: „Panem” lub „Dziedzicem”) i dotyczyły związanej z tym tzw. etykiety określającej zasady pozdrawiania, proszenia, słuchania rozkazu i dziękowania (podwładny zobowiązany był do zdjęcia nakrycia głowy, wyciągnięcia rąk z kieszeni, przyjęcia odpowiedniej postawy i unikania zbyt głośnego mówienia) ${ }^{29}$. Pozostałości patriarchalizmu widoczne były również $\mathrm{w}$ uroczystościach związanych z funkcjonowaniem folwarku, takich jak dożynki czy różnego rodzaju zwyczajowe poczęstunki, „kośne” lub „żniwne"30. Odwołując się do tradycji patriarchalnej, wielu właścicieli rościło sobie prawo do ingerowania $\mathrm{w}$ życie pracowników i ich rodzin w zakresie znacznie wykraczającym poza postanowienia umowne. Od robotników wymagano nie tylko pracy, ale także swoiście rozumianej lojalności („życzliwości”) wobec folwarku, która miała polegać na utożsamianiu się z folwarkiem, podzielaniu poglądów politycznych właściciela, uległości, przywiązaniu i odrzucaniu wszystkiego, co niemiłe właścicielowi (np. przynależności do związków zawodowych). Negatywnie postrzegano opuszczenie folwarku w poszukiwaniu lepszej pracy, za co (po ewentualnym powrocie) karano przesunięciem na mniej płatne stanowisko ${ }^{31}$. Z drugiej strony $\mathrm{w}$ ramach tradycji patriarchalnej właściciel, często przy współudziale swojej żony, ota-

${ }^{28}$ T. Epsztein, Pracownicy w dobrach ziemskich w Polsce w XIX $i$ XX wieku, [w:] Dwór a spoteczności lokalne..., s. 268-272; M. Markowski, Ziemianie jako pracodawcy..., s. 327.

${ }^{29} \mathrm{~W}$ omawianym okresie $\mathrm{w}$ kontaktach z przełożonym starsi podwładni z reguły stosowali etykietę ludową - poddańczą, a młodsi miejską - zawodową. Jednak w jednym i drugim przypadku starano się unikać specjalnej uniżoności, bo to sprzeciwiało się godności ludzkiej i źle świadczyło o charakterze. Por. M. Wachowski, Przygotowanie zawodowe robotnika..., s. 99.

30 Ibidem, s. 52-53, 66.

$31 \mathrm{~W}$ okresie międzywojennym upowszechnił się pogląd, że robotnika rolnego trzeba odpowiednio wychować, od dziecka kształtując jego umiejętności i przywiązanie do majątku. Por. ibidem, s. 110-141. 
czał opieką pracowników i ich rodziny w trakcie chorób lub połogu, organizował ochronki i prezenty świąteczne dla dzieci, biblioteczki i kursy oświatowe oraz popierał przynależność młodzieży do różnego rodzaju stowarzyszeń katolickich, społecznych i sportowych, oczywiście zgodnych z jego poglądami ${ }^{32}$.

W okresie międzywojennym pod wpływem oddziaływania państwa (państwowa szkoła i zakaz pracy dzieci, przymus umów taryfowych i ubezpieczeń socjalnych, nadzór Inspekcji Pracy), demokratycznej postawy części personelu administracyjnego (zwłaszcza młodszego pokolenia) oraz urbanizacji duchowej i innych form tzw. "przetarcia się” (podróże, służba wojskowa, a nawet pobyt w więzieniu) wpływ dworu i czynników z nim związanych na robotnika rolnego był coraz mniejszy 33 . Równocześnie z erozją wpływów patriarchalnych $\mathrm{w}$ sferze stosunków międzyludzkich w folwarku rosło znaczenie czynnika technokratycznego, którego nosicielami byli przedstawiciele administracji gospodarczej, nierzadko legitymujący się wykształceniem akademickim. Ich wiedza i umiejętności w dziedzinie organizacji pracy i zarządzania $\mathrm{w}$ przeważającej mierze decydowały o sukcesie ekonomicznym majątku oraz nastrojach i relacjach panujących wśród podległych im pracowników. Szczególną rolę w tej dziedzinie pełnili rządcy, którzy poza organizowaniem pracy i prowadzeniem spraw gospodarczych zajmowali się kształceniem i wychowywaniem robotników rolnych oraz motywowaniem ich do jak najwydajniejszej pracy. W tym kontekście równie ważne były organizacja pracy (zmierzająca do jak najlepszego wykorzystania dostępnej siły roboczej oraz unikania przeciążenia pracą $\mathrm{z}$ jednej i przestojów z drugiej strony), jak i wynagrodzenie oraz, jak to określano w międzywojniu, „normowanie nastroju pracy” (czyli kształtowanie pozytywnego stosunku pracownika do jego obowiązków) i dawanie przykładu ${ }^{34}$. Było to szczególnie ważne, gdyż robotnicy oczekiwali od rządcy kompetencji w organizowaniu pracy i zdecydowania, ale również znajomości czynności robotniczych, tak by $\mathrm{w}$ razie potrzeby był on w stanie poinstruować, czy wręcz pokazać, jak wykonać konkretną pracę. Od tego w dużej mierze zależał autorytet rządcy, którego robotnicy nierzadko prowokowali do wyko-

32 Postępował w ten sposób znany ze swojego zaangażowania w Akcję Katolicką Edward Potworowski. Por. E. Potworowski, op. cit., s. 40-41; A. Kwilecki, Ziemiaństwo wielkopolskie. Między wsia a miastem, Wydawnictwo Poznańskie, Poznań 2001, s. 189.

33 Wśród robotników rolnych następowało odrzucenie postawy zawodu-losu i niemal sakralnego obowiązku ciężkiej pracy. W to miejsce wchodziły postawy i aspiracje modernizacyjne oraz zawodowa koncepcja życia. W miejsce wartości kulturowych wkraczały wartości ekonomiczne i profesjonalne. Por. M. Wachowski, Przygotowanie zawodowe robotnika..., s. 73-74.

34 J. Walicki, Przyczynek do analizy gospodarstwa folwarcznego, Załącznik do Tomu XXIII Roczników Nauk Rolniczych i Leśnych, Poznań 1930, s. 35-42. 
nywania takich czynności, badając przy okazji jego siłę fizyczną, wytrwałość i umiejętności. Jeśli radził sobie dobrze, to zyskiwał ich szacunek, a w przeciwnym razie narażał się na kompromitację i lekceważenie ${ }^{35}$.

W ten sposób w okresie międzywojennym doszło do odwrócenia hierarchii cnót robotniczych. O ile w systemie poddańczym pracowitość miała wyrastać z wierności, posłuszeństwa i bogobojności, o tyle w omawianym okresie cnoty religijne, moralne i inne stały się czynnikami pomocniczymi w stosunku do cech, które w bezpośredni sposób dotyczyły pracy robotnika, a więc jego umiejętności i wydajności. Podstawowym bodźcem do pracy miało być wynagrodzenie. W związku z tym robotnik nie musiał być religijny, byleby tylko był dobrym i zdyscyplinowanym pracownikiem. Jednocześnie wspomniane wcześniej otwarcie na świat poprzez proste porównanie warunków życia i pracy w folwarkach z warunkami miejskimi wywoływało u robotników rolnych silne poczucie upośledzenia gospodarczego i społecznego, które rosło wraz z rozwojem kryzysu gospodarczego i przyczyniało się do rozwoju ich świadomości klasowej36. Powyższy proces $\mathrm{w}$ kręgach właścicieli ziemskich i osób związanych z rolnictwem był przyczyną narzekań, że pod wpływem kapitalizmu oraz zmaterializowania życia społecznego erozji ulega tradycyjny etos zawodowy robotnika rolnego, co między innymi przyczynia się do jego radykalizacji. Rozumiano jednak nieuchronność i siłę zmian dokonujących się $\mathrm{w}$ otoczeniu i świadomości robotnika rolnego, dlatego pracowano nad stworzeniem nowoczesnej wersji wspomnianego etosu, opartej na zawodowej koncepcji życia. Starano się wywołać wśród robotników, poprzez odwoływanie się do pozytywnych emocji, ,zainteresowanie dla przedsiębiorstwa, dla pracy oraz radość z przebiegu i wyniku pracy", które w ostatecznym rezultacie miały rodzić poczucie dumy i zadowolenia $\mathrm{z}$ faktu bycia robotnikiem rolnym ${ }^{37}$. W okresie międzywojennym majątki ziemskie w Wielkopolsce były również miejscem różnego rodzaju konfliktów pomiędzy pracodawcami i pracobiorcami. Wydarzeniami o największym ciężarze gatunkowym były strajki rolne z lat 1919-1922. W największym z nich w 1922 roku wzięły udział 103 tys. robotników rolnych, czyli około $77 \%$ robotników kontraktowych ${ }^{38}$. Konflikty zbiorowe $\mathrm{i}$ indywidualne $\mathrm{z}$ reguły dotyczyły płac, warunków i jakości pracy, niesubordynacji i nadużywania władzy, potrąceń i zalegania z wypłatami, kra-

${ }^{35}$ M. Wachowski, Przygotowanie zawodowe robotnika..., s. 141-168.

36 Idem, Problemy oświatowe robotnika wielkopolskiego, Poznań 1937, s. 83-85.

37 Ibidem, s. 109.

38 A. Czubiński, op. cit., s. 66-67. Pod wpływem wspomnianych strajków wydane zostały akty prawne dotyczące zasad zatrudniania i warunków pracy robotników rolnych i ubezpieczeń społecznych, co przyczyniło się do zmian w relacjach pomiędzy pracodawcami i pracownikami. 
dzieży i strajków. Na co dzień powszechne były przypadki dręczenia słownego („wyzywanie”) i psychicznego (straszenie) oraz bicia robotników (w tym młodocianych i kobiet), często $\mathrm{z}$ błahego powodu. Celowali w tym administratorzy, zarządcy i inni urzędnicy gospodarczy. Dochodziło do straszenia bronią palną i postrzeleń, a nawet pojedynczych przypadków zastrzelenia. Szczególnie trudne relacje występowały w niektórych majątkach niemieckich, gdzie pracownicy administracji gospodarczej z reguły byli Niemcami, a robotnicy Polakami, przez co obok konfliktów o charakterze ekonomicznym pojawiały się konflikty o charakterze narodowościowym ${ }^{39}$.

Do zaostrzenia konfliktów doszło w okresie kryzysu gospodarczego, gdy z jednej strony właściciele obniżali pracownikom pobory, a z drugiej mnożyły się kradzieże z pól i lasów należących do majątków ${ }^{40}$. Na tym tle w środowisku właścicieli ziemskich wskazywano na wyższość stosunków opartych na zasadach patriarchalnych, które w porównaniu ze stosunkami umownymi gwarantowały wyższy poziom spokoju społecznego. Przyznanie pracownikom nadmiernych, ich zdaniem, praw prowadziło do konfliktów pomiędzy właścicielem a robotnikiem na tle wysokości wynagrodzeń oraz ilości i jakości pracy. Majątki ziemskie zatrudniały największą liczbę pracowników najemnych na wielkopolskiej wsi. Pomimo zmniejszenia się liczby folwarków i zatrudnionych w nich pracowników zdołały utrzymać swoją pozycję $w$ tej dziedzinie przez cały okres międzywojenny. Niewielkim zmianom podlegał również obowiązujący $\mathrm{w}$ majątkach system pracy i wynikające $\mathrm{z}$ niego stosunki pomiędzy pracodawcami, administracją gospodarczą i robotnikami. Wydarzeniami o największym ciężarze gatunkowym $\mathrm{z}$ punktu widzenia stosunków pracy $\mathrm{w}$ folwarkach było wprowadzenie umów zbiorowych w rolnictwie w 1919 roku i kryzys gospodarczy z lat 1929-1936, który postawił je pod znakiem zapytania. Stosunki pracy w majątkach ziemskich powoli ewoluowały. Wynikało to przede wszystkim ze zmian w świadomości robotników rolnych, którzy ulegali duchowej urbanizacji. Wymóg umownego regulowania stosunków pracy w majątkach ziemskich $\mathrm{w}$ połączeniu $\mathrm{z}$ oddziaływaniem polskiej szkoły, służby wojskowej i istnieniem administracji państwowej (w tym szczególnie Inspekcji Pracy)

39 Por. APP, IP, sygn. 38, k. 282, 285, 287-289; S. Warkoczewski, op. cit., s. 129.

40 Odnośnie do kradzieży reakcja administracji gospodarczej była zróżnicowana, gdyż jak twierdził kierownik gospodarstwa w Wąsowie (bardzo wrażliwy na punkcie uczciwości robotnika) - „nie jest złodziejem, kto okolicznościowo zabiera z folwarku niezbyt wiele dla swego bydła. Nie zważa się na to, gdy bardzo często najlepsi robotnicy chętnie coś do domu zabierają. To dobrze, gdy starają się o własny byt. Owe małe pseudozłodziejstwa wiążą robotnika silnie z folwarkiem. Inaczej oceniać trzeba zabieranie większej ilości z pola lub nawet mniejszej ze spichrza". Por. M. Wachowski, Problemy oświatowe..., s. 100. 
powodował zmiany $\mathrm{w}$ świadomości robotników rolnych, skutkujące stopniowym wyzwalaniem się spod patriarchalnych wpływów dworu, umiejętnością samoorganizacji w celu obrony interesów grupowych i poszukiwaniem alternatywnych wobec folwarku dróg kariery zawodowej, jeśli nie dla siebie, to przynajmniej dla co zdolniejszych dzieci. Z drugiej strony właściciele szukali nowych sposobów dyscyplinowania pracowników i wiązania ich z folwarkiem. Różnymi sposobami starali się kształtować świadomość robotników w duchu „życzliwości dla folwarku” i zatrzymywać najlepszych pracowników, co nie było łatwe, gdyż w okresie dobrej koniunktury miasto i przemysł oferowały znacznie atrakcyjniejsze zajęcia i zarobki. Narzędziem obrony przed urbanizacją duchową i emigracją do miasta miał być nowy etos robotnika rolnego oparty na zawodowej koncepcji życia i pozytywnym emocjonalnie postrzeganiu pracy w majątku ziemskim.

W latach trzydziestych pod wpływem kryzysu odpływ robotników rolnych ustał. Jednak właściciele ziemscy zmuszeni do racjonalizacji swoich gospodarstw przystąpili do ograniczenia wydatków bieżących i inwestycji, co $\mathrm{w}$ pierwszej kolejności polegało na redukcji zatrudnienia i zmniejszaniu funduszu płac ${ }^{41}$. W prosty sposób prowadziło to do konfliktów ekonomicznych z robotnikami rolnymi, którzy starali się bronić poprzez strajki i na forum Nadzwyczajnej Komisji Rozjemczej, jednak w okresie kryzysu ich pozycja negocjacyjna była coraz słabsza. Wywołane przez kryzys niepewność i pesymizm w odniesieniu do przyszłości gospodarczej wielkiej własności ziemskiej $w$ tejże dekadzie były dodatkowo pogłębiane przez politykę władz państwowych, które konsekwentnie stały na stanowisku kontynuowania parcelacji, oraz przez rozpowszechniające się wśród partii politycznych (od lewicy po prawice) hasło reformy rolnej bez odszkodowania ${ }^{42}$. Wszystko to wywoływało stan niepewności zarówno u właścicieli-pracodawców, jak i u pracobiorców. Przyczyny ekonomiczne i polityczne sprawiły, że wyraźne $\mathrm{w}$ latach dwudziestych procesy modernizacji majątków ziemskich zarówno $w$ sferze technicznej, jak i społecznej ( $w$ tym także w zakresie stosunków pracy) zostały wyhamowane. W latach trzydziestych na powrót umacniały się: patriarchalny model relacji pomiędzy pracodawcami a pracownikami oraz bezwzględna ekonomiczna eksploatacja, jedynie w niewielkim stopniu ograniczana przez słabnące rozwiązania instytucjonalne.

${ }^{41}$ A. Ostrowski, Położenie gospodarcze rolnictwa w Wielkopolsce w roku 1934/35, Wielkopolska Izba Rolnicza, Poznań 1935, s. 30-32.

42 A. Wojtas, Problematyka agrarna w polskiej myśli politycznej 1918-1948, Ludowa Spółdzielnia Wydawnicza, Warszawa 1983, s. 104, 281-282, 352, 406. 


\section{BIBLIOGRAFIA}

Chmielewski K., Ilość osób zatrudnionych w wielkorolnych gospodarstwach poznańskich (lata 1932/33 - 1933/34), „,Roczniki Nauk Rolniczych i Leśnych” vol. XXXIX, Poznań 1937.

Czubiński A., Wielkopolska w latach 1918-1939, Wydawnictwo Poznańskie, Poznań 2000.

Dąbrowski R., Niemieckie majątki obszarnicze w województwach zachodnich w latach 19201939, „Przegląd Zachodniopomorski” 1978, t. XXII, z. 2.

Epsztein T., Pracownicy w dobrach ziemskich w Polsce w XIX $i$ XX wieku, [w:] Dwór a społeczności lokalne na ziemiach polskich w XIX i XX wieku, red. M. Markowski, W. Caban, M. Przeniosło, Wydawnictwo UH-P, Kielce 2008.

Jassem G., Majątek Smogulecki w latach 1918-1937, PTPN, Poznań 1976.

Kowal S., Struktura społeczna Wielkopolski w międzywojennym dwudziestoleciu, Wydawnictwo Naukowe UAM, Poznań 1974.

Kozakiewicz J., Organizacja pracy $i$ wyniki produkcyjne w majątkach ziemskich w okresie międzywojennym, IUNG, Puławy 1986.

Kwilecki A., Ziemiaństwo wielkopolskie. Między wsią a miastem, Wydawnictwo Poznańskie, Poznań 2001.

Markowski M., Ziemianie jako pracodawcy w Drugiej Rzeczypospolitej, [w:] Dwór a społeczności lokalne na ziemiach polskich w XIX i XX wieku, red. M. Markowski, W. Caban, M. Przeniosło, Wydawnictwo UH-P, Kielce 2008.

Mich W., Ideologia polskiego ziemiaństwa 1918-1939, Wydawnictwo UMCS, Lublin 2000.

Mieszczankowski M., Rolnictwo II Rzeczypospolitej, Książka i Wiedza, Warszawa 1983.

Nowakowski S., Geografia gospodarcza Polski zachodniej, t. 1, Pomorska Drukarnia Rolnicza Sp. Akc., Poznań 1929.

Ostrowski A., Położenie gospodarcze rolnictwa w Wielkopolsce w roku 1934/35, Wielkopolska Izba Rolnicza, Poznań 1935.

Potworowski E., Majętność Gola, Rolnicza Drukarnia i Księgarnia Nakładowa, Poznań 1929.

Roszkowski W., Gospodarcza rola większej prywatnej własności ziemskiej w Polsce 1918-1939, Szkoła Główna Planowania i Statystyki, Warszawa 1986.

Roszkowski W., Rolnictwo i leśnictwo, [w:] Problemy gospodarcze drugiej Rzeczypospolitej, red. K. Kozłowski, PWE, Warszawa 1989.

Statystyka Rolna, odbitka z „Miesięcznika Statystycznego” 1922, z. 12.

Wachowski M., Problemy oświatowe robotnika wielkopolskiego, Poznań 1937.

Wachowski M., Przygotowanie zawodowe robotnika rolnego w świetle pedagogiki empirycznej, „Roczniki Nauk Rolniczych i Leśnych” vol. XLVII, Poznań 1939.

Walicki J., Przyczynek do analizy gospodarstwa folwarcznego, Załącznik do Tomu XXIII Roczników Nauk Rolniczych i Leśnych, Poznań 1930.

Walicki J., Zagadnienie zarządzania gospodarstwami folwarcznymi, „Gazeta Rolnicza” 1934, nr 47.

Warkoczewski S., Położenie robotników rolnych w Wielkopolsce w latach 1929-1939, Książka i Wiedza, Warszawa 1965.

Wize K., Położenie robotników rolnych w Poznańskiem po wojnie, Druk. Sp. Akc. „Ostoja”, Poznań 1925.

Wojtas A., Problematyka agrarna w polskiej myśli politycznej 1918-1948, Ludowa Spółdzielnia Wydawnicza, Warszawa 1983. 